\section{THE LAW OF STORMS DEVELOPED*}

II.

$\mathrm{IT}^{\mathrm{T}}$ has been asserted lately that the Gulf Stream has no influence upon storms; that they have no tendency to run toward it or to run upon it; and that what geogra. phers and seamen have always said about the Gulf Stream as a "weather-breeder" and "storm-king" is absurd. I think it can be demonstrated that this well-known popular belief is not absurd.

It is an observation as old as Aristotle, that the storms of the middle latitudes in the Northern Hemisphere advance from west to east. This is obviously partly due to the fact that the winds on their eastern sides are southerly, that they come from the equatorial regions, and hence are highly charged with aqueous vapour. "This vapour is absolutely essential to the sustenance of the storm. Moreover, the law of storms requires that the southeriy winds should enter the storm-vortex on the eastern side, and as this is the side on which the greatest quantity of vapour is found, and the side of greatest condensation, of the greatest crolution of latent heat, hence of the greatest aërial rarefaction and barometric fall, to this side the heavier air from the west will push as into a great hollow. Thus do we actually find that all storms, formed west of the Gulf Stream, are actually propagated toward it. It may be argued from the above facts that the anti-trade winds are thus maintained by storms incessantly making the circuit of the globe within the temperate zone. But in reality, instead of being the effect of storm influence, the anti-trades are originated by independent solar agency, as are the trades, and they are potential and causal in producing the eastward progression of all cyclones. It must be conceded that the pressure of vast aërial currents does serve to force the meteor along with them as the river-eddy is car-

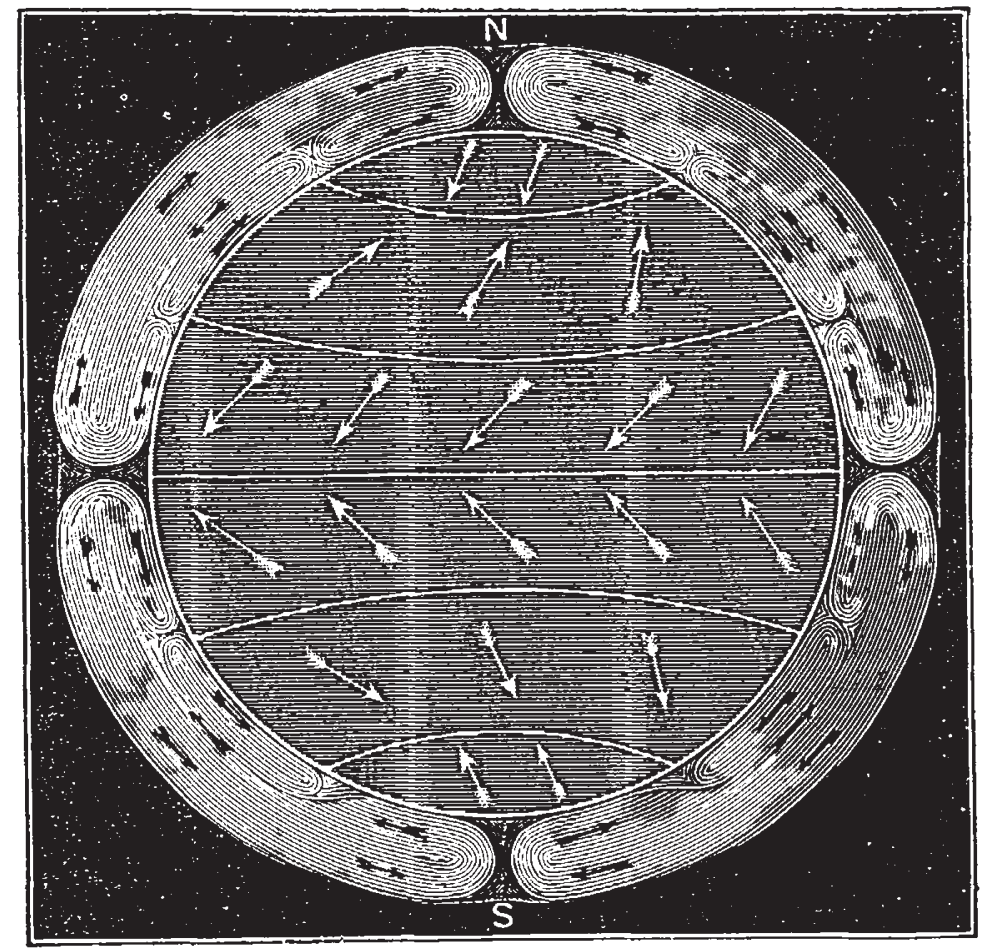

Fig. 3.-The Atmospheric Mlovements.

ried down stream with the water-current; otherwise it is impossible to explain the westward progression of tropical hurricanes. While yet in the band of easterly tradewinds the storm will invariably work its way or be propagated toward the most humid region, unless mechanically borne in another direction by the great atmospheric current in which it is often embedded as an eddy in a river. The cyclone-tracks over all the oceans lie in the central bands of the great ocean-currents of high temperature and great evaporation, and the band of cyclonic violence is often beautifully coterminous with the sharply-marked blue-tinted edge of the Gulf Stream. Thus, in the Pacific, the Loochoo Islands lie just in the path of the Kuro Siwo, the great Pacific Gulf Stream of the Japanese, and are visited by the most fearful typhoons; but the Bonin Islands, in the same parallel, but on the extreme margin of the Kuro Siwo, have very mild and moderate storms.* "If a storm commences anywhere in the vicinity of the Gulf Stream, it naturally tends towards that stream, because," as Loomis says, "here is the greatest amount of vapour to be precipitated, and when a storm has once encountered the Gulf Stream, it continues to follow that stream in its progress eastward." Vessels and Japanese junks, dismasted in gales off the Asiatic coast, have been drifted for many days in the current of the Kuro Siwo, to the coast of California, just as West-Indian beans, cocoa-nuts, and vegetables, have bcen drifted to Iceland, Greenland, and Spitzbergen, on the extension of the Gulf Stream. According to all meteorological observations of the tracks of storms, we are warranted in believing that cyclones and hurricanes do, as a matter of fact and of atmospheric law, run on the hot currents of the sea as naturally as the watercourse clings to its bed. Practical seamen, though unable to 
explain the fact, are always on the look-out for these furious gales when sailing on the axial lines of the Gulf Stream, on the hot Mozambique current (the Gulf Stream of the Indian Ocean), and on the dark superheated waters of the Kuro Siwo of the Pacific.

So dangerous and disastrous are the storms which course along the Gulf Stream that sailors avoid it, and the American Sailing Directions and those of the British Admiralty advise all vessels, sailing from the Wrest Indies to New York or Liverpool, to beware of taking advantage of its current, although it would help thern along from three to four miles an hour. Close observation has traced these storms continuously from the Florida coast to New York, through Redfield's labours, and thence to England, through the records of the Cunard stcamships, and thousands of detached observations.

We have now reached a point where we can properly and intelligently consider a question that has always baffled meteorologists-the origin of cyclones. The diagnosis of the phenomenon necessarily precedes its explanation. This subject has engrossed many minds, and various have been the ingenious devices for unravelling its mystery. MIf. Redticld-the father of storm physics-in his modesty and diffidence, so distrusted himself and in his day so keenly felt the need of a more enlarged induction of facts, that the has scarcely left us his opinion. The theories of other writers have all long since been abandoned by themselves or suffered to drop from the notice of the scientific world as evidently incapable of explaining the phenomena of cyclones. This has been the fate of them all, unless possibly we except the theory advanced by the great meteorologist, Mi. Dové, of Berlin. Bricfly stated, the latter hypothesis is this (at least in its application to WVest Indian hurricanes), viz., that "they owe their origin to the intrusion of the upper counter trade-wird into the lower trade-wind current" (Dovés "Law of Storms," p. 264).

Without pausing here to examine this theory upon its merits and upon the facts, we hasten to mention a different hypothesis advanced, nearly two years ago, as a substitute for that of M. Doite, and as affording an entirely original and satisfactory explanation of the origin of cyclones.

The hypothesis was likewise based upon the agency of the trade-winds, but in a manner wholly different from that elaborated by the Gcrman meteorologist. In the original paper in which my yews were published, the following statement was macle :- If can be demonstrated that the origin of cyclones is found in the tendency of the south-east trade-winds to invade the territory of the northeast trades, by sweeping over the equator into our hemisphere."

The hypothesis advanced, in lieu of another scemingly less satisfactory, claimed to rest upon observations conducted in the very region most notorious for the generation of cyclones.

To test this, we need only to examine the Atlantic trade winds.

Theoretically, physical geography has generaily represented the motions of the atmosphere somewhat as is represented in the accompanying diagram (Fig. 3 ) of the winds, as projected by Prof. William Ferrel, of Cambridge. The elaborate pages of Prof. Coffin, in his invaluable volume on the "Winds of the Northern Hemisphere," as deduced from myriads of observations, show that the graphic illustration furnished by the diagram is approximately correct.

The region of the trade winds, it will be seen, more than covers the torrid zone of the earth, and at all the seasons of the year overlaps both the northern and southern tropics. While this is theoretically true, and is usually put forth as a fact, it must be accompanied with one or two important qualifications and additions.

Let us see what these are. The well-known oscillation or swinging of the belts of winds to and fro on the meridians, which is kept up in never-ceasing response to the apparent annual motion of the sun as he crosses and recrosses the equator, must ever underlie the conception we form of the trade winds and be perpetually present to the mind's eye. This oscillation has never yet received the popular attention it needs. The sun traverses (apparently) an arc of $233^{\circ}$ on either side of the line; and we might, a priori, suppose that the thermal or meteorological equator, the thermal or meteorological Tropics of Cancer and Capricorn, and all those phenomena which lie between them and beyond them, move over an arc of as many degrees as they traverse. Such an inference, how ever, is not borne out by observation, and we propose to confine oursclves strictly to what may be proved by observation. It is clear that the tradewind belt does traverse or vibrate over a wider zone than any physicist has yet assigned to it, which is not more than ten degrees of latitude north and south respectively of the Tropic of Cancer and that of Capricorn. These winds, when first experienced by Spanish sailors, gave, to that portion of the Atlantic over which they blew; the name el Golfo de las Damas (the Ladies' Sea) because they rendered navigation so easy that a girl might tale the helm. But, "gentle" as they are, they have a wide sweep, and, in the summer of the Northern Hemisphere, extend far beyond the Tropic of Cancer. They have often been distinctly felt at Madeira and the Azores (near the 4oth parallel) in summer, and it is highly reasonable to suppose that they then fully reach the latitude of $40^{\circ} \mathrm{N}$. The equatorial side of the north-cast trade-wind belt, of course, vibrates with the sun. In summer it stretches along between the roth and 12th parallels of north latitude, verging in August on the I 3 th parallel, and, according to one writer, occasionally the north-east trades at that season do not extend south of the 15 th parallel of north latitude Dampier, "the prince of navigation," as the English call him, gives the direction of the wind in the summer moriths, between the equator and $12^{\circ}$ north, as south. south-east, south-south-west, and south-west.

The equatorial side of the north-east trade-wind belt in winter approaches very nearly to the equator, and may be located in.January at least as far south as the latitude of $2^{\circ}$ north.

The freshest trade-ivinds in the North Atlantic are generally found between the parallels of $10^{\circ}$ and $25^{\circ}$, and by long protracted experimient in seamanship they have been found to have an avcrage propelling power, when the wind is taken just abaft the beam, of about six knots an hour. But, of course, the northern boundary of the south-east trade-wind likewise varies and vibrates with the seasons. So also, and under the same condition, does the southern boundary of this trade vary and vibrate with the seasons. Its normal and mean position is a little south of the parallel of $25^{\circ}$ south, but in the winter of our hemisphere it is pushed much farther south, and in the vicinity of $35^{\circ}$ south latitude. The charts of Captain Wilkes give easterly winds for the cast coast of Australia, and also for the south coast of Africa. Sir John Herschel, sperking from knowledge gained by his long residence at the Cape of Good Hope, tells us that there "the southeasterly winds which sweep over the Southern Ocean, infringing upon the long range of rocks which terminates in the Table Mountain, is thrown up by them, malics a clean sweep over the flat table-land which forms the summit of that mountain (about $3,850 \mathrm{ft}$. high), and thence plunges down with the violence of a cataract" ("Neteorology," p. 96).

From these high southern latitudes, we must conceive the motion of the south-cast trades, extending northward in summer to the neighbourhood of the parallel of $10^{\circ}$.

T. B. MAURY 